\title{
Association of the 103I MC4R allele with decreased body mass in 7937 participants of two population based surveys
}

\author{
I M Heid, C Vollmert, A Hinney, A Döring, F Geller, H Löwel, H-E Wichmann, T Illig, J Hebebrand, \\ $F$ Kronenberg, the KORA group
}

J Med Genet 2005;42:e21 (http://www.jmedgenet.com/cgi/content/full/42/4/e21). doi: 10.1136/jmg.2004.027011

Background: The melanocortin-4-receptor gene (MC4R) is part of the melanocortinergic pathway that controls energy homeostasis. In a recent meta-analysis, the MC4R V103I (rs2229616) polymorphism was shown to be associated with body weight regulation. Although no functional differences between the isoleucine comprising receptor and the wild type receptor have been detected as yet, this meta-analysis of 14 case-control studies reported a mild negative association with obesity (odds ratio (OR) 0.69, p=0.03). However, evidence in a large population based study in a homogeneous population and a significant estimate of the change in quantitative measures of obesity is still lacking.

Methods: We analysed the data of two surveys of a white population with the same high quality study protocol, giving a total of 7937 participants.

Results: By linear regression, we found a significant decrease of 0.52 body mass index (BMI) units ( $95 \%$ confidence interval (CI) -0.02 to $-1.03, p=0.043$ ) for carriers of the heterozygote rs2229616G/A genotype, which was observed in $3.7 \%$ of the participants. Logistic regression yielded a significantly negative association of the MC4R variant with "above average weight" (BMI $\geqslant$ median BMI) yielding an OR of 0.75 (95\% $\mathrm{Cl} 0.59$ to $0.95 \mathrm{p}=0.017)$. We obtained similar results comparing obese $\left(B M I \geqslant 30 \mathrm{~kg} / \mathrm{m}^{2}\right.$, World Health Organization results for 1997) with non-obese $\left(B M I<30 \mathrm{~kg} / \mathrm{m}^{2}\right.$ ) participants. The results were found for both sexes and each survey separately, and did not depend on the modelling of age, sex, or survey effects.

Conclusions: Our study confirms previous findings of a metaanalysis that the relatively infrequent G/A genotype of the V103I MC4R polymorphism is negatively associated with above average weight and obesity in population based original data of 7937 participants, and extends previous findings by showing for the first time a significantly lower BMI in individuals carrying the infrequent allele of this MC4R variant.

\footnotetext{
$\mathrm{T}$
} he melanocortin-4 receptor gene $(M C 4 R)$ is part of the melanocortinergic pathway, which controls energy homeostasis, and it was recently suggested to be a major gene for obesity. ${ }^{12}$ MC4R mutations have been detected in up to $6 \%$ of obese individuals. ${ }^{2}{ }^{3}$ The isoleucine allele of the V103I polymorphism (rs2229616; G/A) has been found in $\sim 3 \%$ of individuals in white populations and is thus the most common among the MC4R variants. ${ }^{2}$ Although pharmacological studies have not detected functional differences between the isoleucine comprising receptor and the wild type receptor, ${ }^{14}$ a meta-analysis of 14 case-control studies reported a negative association of the 103 isoleucine allele with obesity (odds ratio $(\mathrm{OR}) 0.69, \mathrm{p}=0.03$ ). Therefore, this variant or a variant in linkage disequilibrium or the respective haplotype were suggested to cause a moderate gain of function of MC4R. ${ }^{4}$

In the recent meta-analysis, the infrequent MC4R 103I allele was shown to be negatively associated with obesity. ${ }^{4}$ The initial finding was based on a significantly reduced transmission of the 103I allele in 520 trios ascertained via an obese offspring. The subsequent meta-analysis, comprising 7713 individuals from 14 studies was performed using heterogeneous definitions of "obesity" and involved heterogeneous populations. Furthermore, subjects with intermediate BMI were disregarded in all but four studies, as only obese (defined by the 90th BMI percentile or by the cutoff points $28,30,35$, or $40 \mathrm{~kg} / \mathrm{m}^{2}$ depending on the study) and non-obese subjects (defined by the 50th BMI percentile or the cutoff points $22,25,20$, or $30 \mathrm{~kg} / \mathrm{m}^{2}$ depending on the study) were included. A change in BMI of $0.48 \mathrm{~kg} / \mathrm{m}^{2}$ by the rare $M C 4 R$ variant, which lacked statistical significance $(p=0.22)$ was found by quantitative analysis based on one of the studies. ${ }^{4}$ Although the meta-analysis was an important step in providing first evidence for an association of this $M C 4 R$ variant with human obesity, more and higher quality data are required to validate the finding on a population basis.

It was the aim of our investigation not only to show a negative association between the MC4R 103I variant and obesity on a population basis, but also to specify the extent to which the variant is associated with decreased body mass. We therefore analysed the data from two large population based surveys from the Augsburg region of southern Germany: one survey for the years 1994-1995 (S3) and one for 1999-2001 (S4). In the present study, 7937 participants were thus analysed with respect to MC4R 103I, which, to our knowledge, is one of the largest population based genetic association studies on obesity performed to date.

\section{MATERIAL AND METHODS}

The study data

In the southern German region of Augsburg including the city of Augsburg and the two surrounding counties, population based surveys of the 25-74 year old population in groups of 5 year age range were implemented in 1984 as part of the WHO MONICA (multinational MONItoring of trends and determinants in CArdiovascular disease) project and continued since 1996 within the KORA (KAoperative Gesundheitsforschung in der Region Augsburg) platform. The aims of the surveys were to describe the prevalence of common diseases and their risk factors in a representative sample of the adult general population. ${ }^{6}$

The current study used the survey of the years 1994-1995 (MONICA, S3) comprising 4856 participants and the survey of the years 1999-2001 (KORA, S4) comprising 4261 participants, yielding 9117 recruited participants. The study 


\begin{tabular}{|c|c|c|}
\hline $\begin{array}{l}\text { KORA S3 }(1994 / 95) \\
\mathrm{n}=4856\end{array}$ & \multicolumn{2}{|c|}{$\begin{array}{l}\text { KORA S4 }(1999 / 2001) \\
n=4261\end{array}$} \\
\hline$\checkmark$ & \multicolumn{2}{|c|}{$i$} \\
\hline \multirow[t]{2}{*}{$\begin{array}{l}\text { Analysed sample } \\
n=4071\end{array}$} & \multicolumn{2}{|c|}{$\begin{array}{l}\text { Analysed sample } \\
n=3866\end{array}$} \\
\hline & $\begin{array}{l}\text { BMI } \geq 50 \text { th } \\
\text { and } \leq 90 \text { th } \\
\text { percentile } \\
\mathrm{n}=1532\end{array}$ & $\begin{array}{l}\mathrm{BMl}<50 \text { th } \\
\text { and }>90 \text { th } \\
\text { percentile } \\
\mathrm{n}=2334^{\star}\end{array}$ \\
\hline$\downarrow$ & \multicolumn{2}{|c|}{ 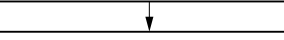 } \\
\hline \multicolumn{3}{|c|}{ Pooled analysis $n=7937$} \\
\hline
\end{tabular}

Figure 1 Overview of the composition of the pooled analysed data from the two surveys. ${ }^{*}$ Included in meta-analysis by Geller et al. ${ }^{4}$

population of S3 and S4 comprised all German residents of the Augsburg region born between 1920 and 1975 identified through the public record office. More than $99.5 \%$ of the participants were white. The high standards of the WHO MONICA project applied to both surveys. All study participants underwent a standardised interview, physical examination, and blood withdrawal by trained staff. They gave informed written consent on a form of the Bavarian ethics committee and the ethics committee of the University of Munich.

For determination of body weight and height, participants were asked to remove shoes and heavy clothing. The weight measurements were performed with a calibrated body weight scale (SECA 709) and were carried out with an accuracy of $0.1 \mathrm{~kg}$. The body height was read to the nearest $0.5 \mathrm{~cm}$ on a body height scale. BMI $\left(\mathrm{kg} / \mathrm{m}^{2}\right)$ was calculated as weight in kilograms divided by height in square metres. All participants of S3 and S4 with available DNA and BMI were eligible and genotyped with respect to MC4R V103I. Genotyping was performed using a matrix assisted laser desorption/ionization time of flight (MALDI-TOF) mass spectrometry system
(Sequenom, Mass EXTEND, San Diego, USA) as described earlier. ${ }^{4}$ The call rates were $99.3 \%$ and $97.9 \%$, respectively, for S3 and S4.

The pooled data analysis included 7937 individuals with complete information on age, sex, BMI, and the MC4R genotype, 4071 from S3 and 3866 from S4. There was no overlap between the two surveys by design. From S4, individuals with a BMI $<50$ th percentile or $\geqslant 90$ th percentile $(\mathrm{n}=2334 ; 60 \%$ of the data from that particular survey) had already been included in the aforementioned meta-analysis. ${ }^{4}$ The composition and derivation of the analysed pooled sample is summarised in fig 1 .

\section{Statistical methods}

Two different statistical approaches were applied to analyse this association in the 7937 participants representative of the southern German population. Firstly, using a linear regression model with BMI as continuous outcome for each study separately and for both studies combined, the unit change in BMI by the MC4R 103I variant was estimated. Secondly, by logistic regression analysis, we computed OR estimates using two different BMI cut off points: $(a)$ individuals with BMI $\geqslant$ the age, sex, and survey specific median BMI ("above average BMI") compared with those with BMI below the median (the respective median BMI for each age, sex, and study stratum are shown in table 1$)$; and $(b)$ individuals with BMI $\geqslant 30 \mathrm{~kg} / \mathrm{m}^{2}$ ("obese" according to the WHO definition) compared with those with BMI $<30 \mathrm{~kg} / \mathrm{m}^{2}$.

All analyses were adjusted for gender and 5 year age groups assuming a trend per group. Interaction effects of age and sex or the $M C 4 R$ variant were explored. In the combined analysis, an effect of the study was additionally estimated; heterogeneity of the studies was tested by including interaction of study with any of the covariates in the model (MC4R polymorphism, age group, sex).

\section{RESULTS}

In the present investigation, two population based surveys from the Augsburg region with complete genotype and

Table 1 Subject characteristics in the analysed samples of the two surveys

\begin{tabular}{|c|c|c|c|c|}
\hline & \multicolumn{2}{|c|}{ Survey S3 (1994/1995) } & \multicolumn{2}{|c|}{ Survey S4 (1999-2001) } \\
\hline & Men & Women & Men & Women \\
\hline \multicolumn{5}{|l|}{ Number of subjects } \\
\hline & 2019 & 2052 & 1919 & 1947 \\
\hline \multicolumn{5}{|c|}{ By BMI WHO category $\left(\mathrm{kg} / \mathrm{m}^{2}\right)$} \\
\hline$<18.5$ & $6(0.3 \%)$ & $16(0.8 \%)$ & $4(0.2 \%)$ & $20(1.0 \%)$ \\
\hline $18.5-20$ & $537(26.6 \%)$ & $886(43.2 \%)$ & $494(25.7 \%)$ & 779 (40.0\%) \\
\hline $25-30$ & $1084(53.7 \%)$ & $693(33.8 \%)$ & $994(51.8 \%)$ & $676(34.7 \%)$ \\
\hline $30-35$ & $328(16.2 \%)$ & $320(15.6 \%)$ & $344(17.9 \%)$ & $324(16.6 \%)$ \\
\hline $35-40$ & $54(2.7 \%)$ & $102(5.0 \%)$ & $60(3.1 \%)$ & $112(5.7 \%)$ \\
\hline $40+$ & $10(0.5 \%)$ & $35(1.7 \%)$ & $23(1.2 \%)$ & $36(1.8 \%)$ \\
\hline \multicolumn{5}{|l|}{ By obesity status } \\
\hline $\mathrm{BMI} \geqslant 30$ & 392 (19.4\%) & $457(22.3 \%)$ & $427(22.2 \%)$ & 472 (24.2\%) \\
\hline $\mathrm{BMI}<30$ & $1627(80.6 \%)$ & $1595(77.7 \%)$ & $1492(77.8 \%)$ & $1475(75.8 \%)$ \\
\hline \multicolumn{5}{|l|}{ BMI $\left(\mathrm{kg} / \mathrm{m}^{2}\right)$} \\
\hline Min-max & $16-46$ & $14-57$ & $16-55$ & $16-51$ \\
\hline p50*, p90† & $27 / 32$ & $26 / 33$ & $27 / 32$ & $26 / 34$ \\
\hline \multicolumn{5}{|c|}{ p50/p90 by age group } \\
\hline $25-30$ & $24.5 / 28.0$ & $22.4 / 27.6$ & $24.8 / 29.3$ & $22.8 / 30.0$ \\
\hline $30-35$ & $25.8 / 31.1$ & $23.0 / 30.0$ & $25.5 / 30.4$ & $23.8 / 31.6$ \\
\hline $35-40$ & $26.2 / 31.9$ & $24.0 / 31.9$ & $26.4 / 30.9$ & $24.4 / 31.0$ \\
\hline $40-45$ & $26.6 / 31.7$ & $24.0 / 31.9$ & $26.6 / 31.4$ & $24.5 / 33.2$ \\
\hline $45-50$ & $27.1 / 31.7$ & $25.9 / 33.1$ & $27.1 / 33.1$ & $26.1 / 34.0$ \\
\hline $50-55$ & $27.7 / 33.4$ & $26.6 / 33.7$ & $28.1 / 34.3$ & $26.8 / 34.5$ \\
\hline $55-60$ & $27.6 / 32.5$ & $27.0 / 33.4$ & $26.9 / 32.7$ & $27.3 / 34.8$ \\
\hline $60-65$ & $28.2 / 32.9$ & $28.2 / 36.1$ & $27.9 / 32.8$ & $28.4 / 36.2$ \\
\hline $65-70$ & $28.0 / 32.6$ & $28.8 / 35.2$ & $28.4 / 34.3$ & $29.0 / 35.5$ \\
\hline $70-74$ & $27.4 / 31.3$ & $27.9 / 34.8$ & $28.5 / 33.0$ & $28.6 / 34.0$ \\
\hline
\end{tabular}


phenotype information, comprising 7937 individuals, were analysed. Subject characteristics are summarised in table 1. The participants were $25-74$ years of age; about $50 \%$ were older than 50 years and about $50 \%$ were men. The range of BMI was $14-57 \mathrm{~kg} / \mathrm{m}^{2}$ (S3) or $16-55 \mathrm{~kg} / \mathrm{m}^{2}$ (S4), respectively.

With respect to the genotype distribution, $3.7 \%$ of the participants showed the heterozygous G/A genotype in S3, $3.6 \%$ in S4. None of the participants was homozygous for the infrequent $\mathrm{A}$ allele in S3. In S4, there was a single subject with the A/A genotype (a 33 year old man with BMI $23.89 \mathrm{~kg} / \mathrm{m}^{2}$ ), who was included in the analysis, but not treated differently from the heterozygous participants. The observed allele frequency of $1.85 \%$ agrees with the according to the Hardy-Weinberg equilibrium expected number of 2.7 A/A subjects among the 7937 participants. Mean (SD) BMI was 27.1 (4.6) kg/m ${ }^{2}$ and $26.6(3.9) \mathrm{kg} / \mathrm{m}^{2}$ among the noncarriers $(\mathrm{G} / \mathrm{G})$ and the carriers $(\mathrm{A} / \mathrm{G})$, respectively.

Table 2 summarises the frequencies of the genotype G/A by sex and various categories of BMI. The frequency of the G/A genotype was lower among those with above average weight overall and in all subgroups (for each survey and each gender separately). In addition, if other groups of BMI (obese versus non-obese, WHO categories) are considered, there was a clear trend towards lower G/A frequencies in the obese or in the higher WHO categories overall and in most of the subgroups (by sex and survey), except for the men in S4.

The two surveys were not only homogeneous in terms of the genotype distribution, but also in the age and sex dependency of BMI-that is, the BMI depended on age and sex in a similar manner in both surveys. In fig 2, we visualised the mean BMI per age group by sex separately for both surveys. This clearly indicates an upward age trend in BMI for both sexes, which is very similar in both surveys. In the younger age groups, women exhibited lower BMIs than men, but showed a steeper increase matching the male BMI at the age of about 50 years. Therefore, we allowed for an extra increase in BMI per age group for women in the regression analyses, which proved to be highly statistically significant $(\mathrm{p}<0.0001)$. Furthermore, the S4 (conducted 1999/2001) BMI levels were higher, particular in the younger age groups, than the S3 (1994/1995) BMI levels.

The results of the association analysis are summarised in table 3. Firstly, linear regression of the combined data $(\mathrm{n}=7939)$ with BMI as continuous outcome showed a significant decrease in BMI of -0.52 BMI points (95\% CI -0.02 to $-1.03, p=0.043$ ) for the $G / A$ genotype compared with the wildtype $(G / G)$. The trend was observed in almost all investigated subgroups (for each survey and each gender), but was not significant in any of the subgroups.

Table 3 also states the estimates of the covariates sex, study, and age group, and the additional effect of the age group for women in the model, which showed: (a) an increase of 2.21 BMI points for men $(\mathrm{p}<0.0001)$; $(b)$ an increase of 0.36 BMI points per 5 years of age $(p<0.0001)$; (c) an additional increase of the slope of the BMI-age relationship of 0.29 for women, yielding a total increase of about 0.7 BMI points per 5 years of age for women $(\mathrm{p}<0.0001)$; and $(d)$ an increase of $0.28(\mathrm{p}<0.003)$ BMI points for the survey effect of S4 (compared with S3). All estimates of these covariates were highly significant and homogenous across the surveys. The increase of BMI in survey S4 compared with S3 was statistically significant $(p=0.003)$, as suggested by comparison of fig $2 \mathrm{~A}$ and $\mathrm{B}$.

Even with different modelling of the age, sex, or survey effects, the genotype effect remained unaltered. None of the explored interactions other than the aforementioned modifying effect of sex on the age-BMI relationship were present; there was no heterogeneity of the genotype effect in the two surveys, and no interaction between genotype and age or sex.
Table 2 Genotype frequencies for the surveys S3 (1994-1995) and S4 (1999-2001)

\begin{tabular}{|c|c|c|c|}
\hline & \multicolumn{3}{|c|}{ Genotype frequencies } \\
\hline & All & Men & Women \\
\hline \multicolumn{4}{|l|}{ S3 } \\
\hline Number of subjects & 4071 & 2019 & 2052 \\
\hline \multicolumn{4}{|l|}{$\%$ with $G / A^{*}(n)$} \\
\hline All & $3.7(152)$ & $4.5(90)$ & $3.0(62)$ \\
\hline \multicolumn{4}{|c|}{ By below/above average weight } \\
\hline $\mathrm{BMl}<\mathrm{p} 50+(\mathrm{n}=2026)$ & $4.2(86)$ & $5.2(52)$ & $3.3(34)$ \\
\hline $\mathrm{BMI} \geqslant \mathrm{p} 50(\mathrm{n}=2045)$ & $3.2(66)$ & $3.7(38)$ & $2.7(28)$ \\
\hline \multicolumn{4}{|l|}{ By obesity status } \\
\hline $\mathrm{BMI}<30(\mathrm{n}=3222)$ & $4.1(131)$ & $4.8(78)$ & $3.3(53)$ \\
\hline$B M I \geqslant 30(n=849)$ & $2.5(21)$ & $3.1(12)$ & $2.0(9)$ \\
\hline \multicolumn{4}{|l|}{ By BMI WHO category } \\
\hline $\mathrm{BMI}<18.5(\mathrm{n}=22)$ & $4.5(1)$ & $0.0(0)$ & $6.2(1)$ \\
\hline BMI $18.5-25(n=1423)$ & $3.6(51)$ & $5.6(30)$ & $2.4(21)$ \\
\hline BMI $25-30(n=1777)$ & $4.4(79)$ & $4.4(48)$ & $4.5(31)$ \\
\hline BMI $30-35(n=648)$ & $2.8(18)$ & $3.0(10)$ & $2.5(8)$ \\
\hline BMI 35-40 $(n=156)$ & $1.9(3)$ & $3.7(2)$ & $1.0(1)$ \\
\hline $\mathrm{BMI} 40+(n=45)$ & $0(0)$ & $0(0)$ & $0(0)$ \\
\hline \multicolumn{4}{|l|}{ S4 } \\
\hline Number of subjects & 3866 & 1919 & 1947 \\
\hline \multicolumn{4}{|l|}{$\%$ with $G / A$ or $A / A \ddagger(n)$} \\
\hline All & $3.6(139)$ & 3.7 (72) & $3.4(67)$ \\
\hline \multicolumn{4}{|c|}{ By below/above average weight } \\
\hline $\mathrm{BMI}<\mathrm{p} 50+(\mathrm{n}=1926)$ & $4.1(79)$ & $4.0(38)$ & $4.2(41)$ \\
\hline $\mathrm{BMI} \geqslant \mathrm{p} 50(n=1940)$ & $3.1(60)$ & 3.5 (34) & $2.7(26)$ \\
\hline \multicolumn{4}{|l|}{ By obesity status: } \\
\hline $\mathrm{BMl}<30(\mathrm{n}=2955)$ & $3.8(112)$ & $3.7(55)$ & $3.9(57)$ \\
\hline$B M I \geqslant 30(n=899)$ & $3.0(27)$ & 4.0 (17) & $2.1(10)$ \\
\hline \multicolumn{4}{|l|}{ By BMI WHO category } \\
\hline $\mathrm{BMI}<18.5(\mathrm{n}=24)$ & $0.0(0)$ & $0.0(0)$ & $0.0(0)$ \\
\hline BMI $20-25(n=1273)$ & $4.1(53)$ & 3.7 (18) & $4.5(35)$ \\
\hline BMI $25-30(n=1670)$ & $3.5(59)$ & $3.7(37)$ & $3.2(22)$ \\
\hline BMI $30-35(n=668)$ & $3.3(22)$ & $3.8(13)$ & $2.8(9)$ \\
\hline BMI $35-40(n=172)$ & $2.3(4)$ & 5.0 (3) & $0.9(1)$ \\
\hline BMI $40+(n=59)$ & $1.7(1)$ & $4.3(1)$ & $0(0)$ \\
\hline
\end{tabular}

*No subject with $\mathrm{A} / \mathrm{A} ; \mathrm{tp} 50$ = age, sex, and survey specific 50 th percentile of $\mathrm{BMl}$; fone subject with $\mathrm{A} / \mathrm{A}$.

Secondly, using a logistic regression model, we computed OR estimates comparing above average weight participants (individuals with BMI $\geqslant$ the age, sex, and study specific median BMI, $\mathrm{n}=3985$ ) versus below average weight participants $(n=3952)$. For this analysis, the covariate effects are not shown as they were all practically zero owing to the fact that age, sex, and survey specific cutoff points were chosen. A significantly lower OR of 0.75 (table 3, 95\% CI 0.59 to $0.95, p=0.017$ ) was estimated. As the definition of above average weight was made by the age, sex, and survey specific median BMI, no age, sex, or survey effects remained in this comparison. The association was apparent not only for above average weight participants, but also for obese subjects; comparing individuals with $\mathrm{BMI} \geqslant 30$ versus $\mathrm{BMI}$ $<30$ yielded a significantly decreased OR of 0.69 (95\% CI 0.50 to $0.96, \mathrm{p}=0.026$ ).

\section{DISCUSSION}

\section{$M C 4 R$ as a candidate gene}

Genetic studies have pointed to the importance of the melanocortin system in several complex human pathways such as pigmentation, severe hyperinsulinaemia, lipolysis, food intake, thermogenesis, sexual behaviour, memory, and inflammatory response. ${ }^{35-10}$ Because MC4R is part of the melanocortinergic pathway that controls energy homeostasis and plays a key role in body weight regulation, the corresponding gene is a likely candidate for obesity.

The major gene effect of the MC4R in obesity is well known; ${ }^{181319}$ up to $6 \%$ of obese individuals show a functionally relevant mutation in this gene. ${ }^{23}$ These mutations often result in BMIs larger than $30 \mathrm{~kg} / \mathrm{m}^{2}$ due to either 



Figure 2 Age-BMI relationship by gender and survey: mean BMI for each 5 year age group for men (solid line) and for women (broken line) (A) survey S3 (1994/1995), (B) survey S4 (1991/2001). It is clear that this relationship is homogeneous for both surveys. An intercept can be observed for men versus women and a secular trend with higher BMls in the later survey (S4) can be seen particularly for the 25-60 year olds.

loss of function or reduced function. Recently, the melanocortins and their receptors have become the target for drug based treatment of human physiological processes; for example, $M C 3 R$ and $M C 4 R$ are likely targets for controlling body weight. Because functional differences between the isoleucine comprising and the wildtype receptor have not been detected, ${ }^{12}{ }^{12}{ }^{20}$ it is unclear if the isoleucine variant in itself underlies our finding. Therefore, we cannot exclude that the V103I variant is in linkage disequilibrium with an unidentified causative functional polymorphism in the $5^{\prime}$ or $3^{\prime}$ region of the $M C 4 R .^{411}$

It was the aim of this investigation to clarify the association between the MC4R 103I variant and decreased body mass in a general white population and to provide clear evidence on the extent of this decrease. The presented pooled analysis of two population based surveys comprising 7937 participants confirmed and extended previous findings of a negative association of the G/A genotype of the MC4R V103I polymorphism and obesity.

\section{Association of the 1031 with decreased BMI}

We found a significant decrease in BMI of $0.52 \mathrm{~kg} / \mathrm{m}^{2}$ by the G/A MC4R genotype ( $95 \%$ CI -1.03 to $-0.02, \mathrm{p}=0.043$ ). Our study is the first to provide a significant estimate of the association of the 103I variant with a quantitative measure of obesity and is the first singular study of considerable size to prove such an association. To our knowledge, it is one of the largest population based association studies on genetic effects on obesity to date investigating a homogeneous population. A similar estimate of $-0.48 \mathrm{~kg} / \mathrm{m}^{2}(\mathrm{p}=0.22)$ was described previously, but lacked power and consequently statistical significance. ${ }^{4}$ Analysing the subgroups (each survey and each gender separately) using sensitivity analyses, the same tendency was found, but given the small effect size, the results were not significant due to the smaller subgroup sample sizes. For both surveys combined, the G/A genotype effect estimate for women was double that for men $\left(-0.74 \mathrm{~kg} / \mathrm{m}^{2}\right.$ versus $-0.35 \mathrm{~kg} / \mathrm{m}^{2}$ ) being in line with a gender effect for MC4R mutations as described by Dempfle et al. ${ }^{19}$ However, the gender difference was not significant overall and in fact only pronounced in S4, but not in S3 (table 3).

\section{Negative association of 1031 with above average weight and obesity}

We found a significant association of the G/A MC4R genotype with being above average weight (defined as exceeding the age, sex, and survey specific median BMI compared with being below average weight) (OR $0.75,95 \%$ CI 0.59 to 0.95 , $\mathrm{p}=0.017$ ) as well as with being obese (defined as BMI $\geqslant 30 \mathrm{~kg} / \mathrm{m}^{2}$ according to the WHO definition) compared with being non-obese (defined as BMI $<30 \mathrm{~kg} / \mathrm{m}^{2}$ ) (OR 0.69, 95\% CI 0.50 to $0.96, p=0.026)$. In two respects, our results extend the finding from the meta-analysis, ${ }^{4}$ which revealed an OR of 0.69 ( $95 \%$ CI 0.50 to $0.96, p=0.03$ ) comparing the obese and extremely obese with normal subjects in a total of 7713 participants from 14 studies in two ways. Firstly, our results confirm that the meta-analysis effect did not result from publication or selection bias by finding a comparable effect in a population based setting with 7937 subjects from one study. Secondly, being able to show significantly reduced ORs comparing subjects with above average BMI with those lower than the average indicates that the effect does not apply to only the extreme groups. The G/A genotype was observed in $3.7 \%$ of the participants in both of our surveys, which is in line with previous reports on white populations. ${ }^{12-15}$

\section{Age, sex, and survey effects}

Regarding the age and sex effects on BMI, we observed (a) a very homogeneous increase of BMI by age of $0.3 \mathrm{~kg} / \mathrm{m}^{2}$ per 5 years of age for men and approximately $0.7 \mathrm{~kg} / \mathrm{m}^{2}$ for women across the two surveys, and $(b)$ a higher BMI for men (table 3, fig 2). Further, we found a highly significant survey effect of $+0.3 \mathrm{~kg} / \mathrm{m}^{2}$ for S4 compared with S3, indicating that the 25-75 year old population of the study region of the years 1999-2001 had on average an increased BMI of $+0.3 \mathrm{~kg} / \mathrm{m}^{2}$ compared with the age matched population of the same region 5 years ealier (1994/1995), a result in accordance with the trend towards increasing BMI observed in many countries. These data may illustrate the impact of the change in lifestyle on BMI, as the two surveys are sampled from the same population at two different points in time and a change in the genetics of this population is highly unlikely.

\section{Limitations and strengths of the study}

Regarding limitations of our study, it needs to be noted that our study shares 2334 (383 obese cases and 1951 controls; $29 \%$ of the data presented here) participants with the stated meta-analysis. ${ }^{4}$ Altogether, that meta-analysis was based on 7713 subjects (3631 cases and 4082 controls). However, neither the estimates of the meta-analysis nor those of our study presented here depend only on the common 2334 subjects: similar results (albeit non-significant) were also found analysing survey S3 alone $(n=4071)$, which was not part of the meta-analysis. Among the 14 studies in the metaanalysis, 11 studies showed a negative association (including the 2334 subjects of S4). The OR estimates of the 11 studies for which the OR was computable, were $0.30,0.55,0.58,0.58$, $0.67,0.69,0.74,0.80,0.92,1.08$, and 1.28 . Therefore, the OR estimate of the 2334 subjects from our study of 0.58 was not an extreme one.

The present study has the advantage of being able to use a homogeneous definition of above average weight and obesity, 
Table 3 Association of the MC4R V103I G/A genotype (compared with the wildtype G/G) with BMl as continuous variable via linear regression and with being above average weight (BMI $\geqslant$ age, sex, and survey specific median BMI) via logistic regression

\begin{tabular}{|c|c|c|c|c|}
\hline \multirow[b]{2}{*}{ Study } & \multirow[b]{2}{*}{ Parameter } & \multicolumn{3}{|l|}{ Parameter estimate } \\
\hline & & Allt & Men‡ & Women $\ddagger$ \\
\hline \multicolumn{5}{|c|}{ Unit change in BMl (slope) in $\mathrm{kg} / \mathrm{m}^{2}$} \\
\hline \multirow{5}{*}{$\begin{array}{c}S 3+S 4 \\
(n=7937)\end{array}$} & $G / A^{*}$ genotype $v G / G$ & $-0.52(-1.03$ to -0.02$)(p=0.043)$ & $-0.36(-0.95$ to 0.23$)(p=0.23)$ & $-0.74(-1.59$ to 0.11$)(p=0.09)$ \\
\hline & Age group all & $0.36(0.31$ to 0.41$)(p<0.0001)$ & $0.36(0.32$ to 0.40$)(p<0.0001)$ & $0.65(0.59$ to 0.70$)(p<0.0001)$ \\
\hline & Male & $2.21(1.79$ to 2.63$)(p<0.0001)$ & - & - \\
\hline & Age group for women & $0.29(0.22$ to 0.36$)(p<0.0001)$ & - & - \\
\hline & S4 study effect & $0.28(0.09$ to 0.48$)(p=0.003)$ & $0.20(-0.03$ to 0.43$)(p=0.10)$ & $0.37(0.07$ to 0.67$)(p=0.02)$ \\
\hline \multirow{4}{*}{$\begin{array}{c}S 3 \\
(n=4071)\end{array}$} & G/A genotype $v G / G$ & $-0.61(-1.29$ to 0.06$)(p=0.08)$ & $-0.73(-1.49$ to 0.02$)(p=0.06)$ & $-0.45(-1.64$ to 0.75$)(p=0.46)$ \\
\hline & Age group all & $0.36(0.29$ to 0.42$)(p<0.0001)$ & $0.36(0.30$ to 0.41$)(p<0.0001)$ & $0.68(0.60$ to 0.75$)(p<0.0001)$ \\
\hline & Male & 2.47 (1.91 to 3.04$)(p<0.0001)$ & 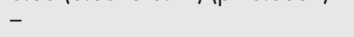 & - \\
\hline & Age group for women & $0.32(0.23$ to 0.42$)(p<0.0001)$ & - & - \\
\hline \multirow{4}{*}{$\begin{array}{c}S 4 \\
(n=3866)\end{array}$} & $G / A^{*}$ genotype $v G / G$ & $-0.44(-1.20$ to 0.32$)(p=0.25)$ & $-0.11(-0.82$ to 1.03$)(p=0.82)$ & $-1.03(-0.82$ to 1.03$)(p=0.10)$ \\
\hline & Age group all & $0.36(0.29$ to 0.44$)(p<0.0001)$ & $0.36(0.30$ to 0.43$)(p<0.0001)$ & $0.62(0.54$ to 0.70$)(p<0.0001)$ \\
\hline & Male & $1.94(1.31$ to 2.56$)(p<0.0001)$ & - & - \\
\hline & Age group for women & $0.26(0.15$ to 0.36$)(p<0.0001)$ & - & - \\
\hline \multicolumn{5}{|c|}{ Relative change of odds of being above average weight (OR) } \\
\hline $\mathrm{S} 3+\mathrm{S} 4$ & $G / A^{*}$ genotype $v G / G$ & $0.75(0.59$ to 0.95$)(p=0.017)$ & $0.78(0.57$ to 1.08$)(p=0.133)$ & $0.71(0.49$ to 1.01$)(p=0.056)$ \\
\hline S3 & $\mathrm{G} / \mathrm{A}$ genotype $v \mathrm{G} / \mathrm{G}$ & $0.75(0.54$ to 1.04$)(p=0.093)$ & $0.71(0.46$ to 1.09$)(p=0.122)$ & $0.81(0.49$ to 1.35$) p=(0.418)$ \\
\hline S4 & $G / A^{*}$ genotype $v G / G$ & $0.75(0.53$ to 1.05$)(p=0.088)$ & $0.88(0.55$ to 1.41$)(p=0.608)$ & $0.62(0.38$ to 1.02$)(p=0.062)$ \\
\hline \multicolumn{5}{|c|}{$\begin{array}{l}\text { Results are the beta estimate (linear regression), or the odds ratio estimate (logistic regression), with } 95 \% \text { confidence interval and p values in parentheses. *The on } \\
\text { subject from S4 with A/A genotype is collapsed into the G/A genotype group; ffull model: adjusted for study, sex, age groups assuming a trend per group and ar } \\
\text { additional change in the BMI-age group relationship for women; ¥sex specific model, adjusted for study, age groups assuming a trend per group. The main result } \\
\text { (S3+S4 together) are bold. }\end{array}$} \\
\hline
\end{tabular}

whereas it was a limitation of the meta-analysis noted by the authors themselves that they used quite heterogeneous definitions across the 14 studies (using cutoff points of 28 , 30,35 , or $40 \mathrm{~kg} / \mathrm{m}^{2}$, or 90 th BMI percentile for the cases and cutoff points of 25,22 , or $30 \mathrm{~kg} / \mathrm{m}^{2}$ or the 50 th BMI percentile for the controls). Further, our study overcomes the potential danger of publication bias inherent in any meta-analysis. Our study is large and population based, pooling the data of two highly homogeneous surveys and addressing age and sex effects on BMI as well as a secular trend between the years 1994-1995 and 1999-2001. Finally, our study uses the full range of BMI in both the quantitative and qualitative analyses, whereas subjects with intermediate BMI were excluded from the meta-analysis.

\section{Summary}

In summary, the present study confirms and extends previous findings of a negative association of the MC4R 103I variant and obesity. We were able to confirm this association in a population based sample comprising 7937 individuals and for the first time to provide significant evidence of a decrease of $0.52 \mathrm{BMI}$ points in subjects with the G/A genotype. Our results substantiate that genetic variation in the MC4R can be associated with both an elevated (mutations) and reduced (V103I polymorphism) body weight. The V103I polymorphism can be viewed as contributing to polygenetically regulated body weight.

\section{ACKNOWLEDGEMENTS, SPONSOR DETAILS}

We thank all study participants. We further thank M Wimmer and A Lämmle for excellent technical assistance and G Fischer for excellent data management. The KORA research platform (KORA, Cooperative Research in the Region of Augsburg) and the MONICA Augsburg studies (Monitoring Trends and Determinants on Cardiovascular Diseases) were initiated and financed by the GSF-National Reseach Centre for Environment and Health, which is funded by the German Federal Ministry of Education and Research and of the State of Bavaria. Genotyping was performed in the GSF genotyping facility located in the Genome Analysis Center (GAC) chaired by J Adamski.
The study was funded by the National Genome Research Net of the German Ministry of Education and Research (OI-GSF0482, UWS15T03, N2NV S31T10).

\section{Authors' affiliations}

I M Heid, C Vollmert, A Döring, H Löwel, H-E Wichmann, T Illig, F Kronenberg, the KORA Group, GSF National Research Center for Environment and Health, Institute of Epidemiology, Neuherberg, Germany

A Hinney, J Hebebrand, Department of Child and Adolescent Psychiatry, University of Duisburg-Essen, Germany

F Geller, Institute of Medical Biometry and Epidemiology, PhilippsUniversity of Marburg, Germany

F Kronenberg, Division of Genetic Epidemiology, Department of Medical Genetics, Molecular and Clinical Pharmacology, Innsbruck Medical University, Austria

Competing interests: none of the authors has in the past 5 years accepted any reimbursement for attending a symposium, any fee for speaking or for organising education, any funds for research or a member of staff, or any fee for consulting from an organisation that may in any way gain or lose financially from the results of our study or the conclusions of our manuscript, nor have they been employed by or hold any stocks or shares in such an organisation. None of the authors has acted as an expert witness on the subject of our study, and they have no other competing financial interests

The KORA group consists of H-E Wichmann (speaker), H Löwel, C Meisinger, T Illig, R Holle, J John, and their coworkers, who are responsible for the design and conduct of the KORA studies. The MONICA Augsburg study was initiated and conducted by $U$ Keil and coworkers. Our work was supported within the German National Genomic Research Network (NGFN) by the Federal Ministry of Education and Research (BMBF).

The first two authors contributed equally to this work.

Correspondence to: Dr T Illig, GSF - National Research Center for Environment and Health, Institute of Epidemiology, Ingolstädter Landstr. 1, 85764 Neuherberg, Germany; illig@gsf.de

Received 15 September 2004

Revised version received 19 January 2005

Accepted 20 January 2005 


\section{REFERENCES}

1 Hinney A, Hohmann S, Geller F, Vogel C, Hess C, Wermter AK, Brokamp B, Goldschmidt H, Siegfried W, Remschmidt H, Schafer H, Gudermann T, Hebebrand J. Melanocortin-4 receptor gene: case-control study and transmission disequilibrium test confirm that functionally relevant mutations are compatible with a major gene effect for extreme obesity. J Clin Endocrinol Metab 2003;88:4258-67.

2 Lubrano-Berthelier C, Durand E, Dubern B, Shapiro A, Dazin P, Weill J, Ferron $C$, Froguel $P$, Vaisse $C$. Intracellular retention is a common characteristic of childhood obesity-associated MC4R mutations. Hum Mol Genet 2003; 12:145-53.

3 O'Rahilly S, Yeo GS, Farooqi IS. Melanocortin receptors weigh in. Nat Med 2004;10:351-2.

4 Geller F, Reichwald K, Dempfle A, Illig T, Vollmert C, Herpertz S, Siffert W, Platzer M, Hess C, Gudermann T, Biebermann H, Wichmann HE, Schafer H, Hinney A, Hebebrand J. Melanocortin-4 receptor gene variant IIO3 is negatively associated with obesity. Am J Hum Genet 2004;74:572-81.

5 Yeo GS, Faroogi IS, Challis BG, Jackson RS, O'Rahilly S. The role of melanocortin signalling in the control of body weight: evidence from human and murine genetic models. Q J Med 2000;93:7-14.

6 Filipiak B, Heinrich J, Nowak D, Wichmann HE. The distribution in specific lgE and the prevalence of allergic symptoms in 25-64-years old inhabitants of an eastern and a western German city - Results from Augsburg and Erfurt. Eur J Epidemiol 2001;17:77-84.

7 Huszar D, Lynch CA, Fairchild-Huntress V, Dunmore JH, Fang Q, Berkemeier LR, Gu W, Kesterson RA, Boston BA, Cone RD, Smith FJ, Campfield LA, Burn P, Lee F. Targeted disruption of the melanocortin-4 receptor results in obesity in mice. Cell 1997;88:131-41.

8 Farooqi IS, Keogh JM, Yeo GS, Lank EJ, Cheetham T, O'Rahilly S. Clinical spectrum of obesity and mutations in the melanocortin 4 receptor gene. N Engl J Med 2003;348:1085-95.

9 Van der Ploeg LH, Martin WJ, Howard AD, Nargund RP, Austin CP, Guan X, Drisko J, Cashen D, Sebhat I, Patchett AA, Figueroa DJ, DiLella AG, Connolly BM, Weinberg DH, Tan CP, Palyha OC, Pong SS, MacNeil T, Rosenblum C, Vongs A, Tang R, Yu H, Sailer AW, Fong TM, Huang C, Tota MR, Chang RS, Stearns R, Tamvakopoulos C, Christ G, Drazen DL, Spar BD, Nelson RJ, Maclntyre DE. A role for the melanocortin 4 receptor in sexual function. Proc Natl Acad Sci USA 2002;99:11381-6.

10 Voisey J, Carroll L, van Daal A. Melanocortins and their receptors and antagonists. Curr Drug Targets 2003;4:586-97.

11 Jonsson L, Skarphedinsson JO, Skuladottir GV, Watanobe H, Schioth HB. Food conversion is transiently affected during 4 -week chronic administration of melanocortin agonist and antagonist in rats. J Endocrinol 2002; 173:517-23.

12 Vaisse C, Clement K, Durand E, Hercberg S, Guy-Grand B, Froguel P. Melanocortin-4 receptor mutations are a frequent and heterogeneous cause of morbid obesity. J Clin Invest 2000;106:253-62.

13 Hinney A, Schmidt A, Nottebom K, Heibult O, Becker I, Ziegler A, Gerber G, Sina M, Gorg T, Mayer H, Siegfried W, Fichter M, Remschmidt H, Hebebrand J. Several mutations in the melanocortin-4 receptor gene including a nonsense and a frameshift mutation associated with dominantly inherited obesity in humans. J Clin Endocrinol Metab 1999;84: 1483-6

14 Farooqi IS, Yeo GS, Keogh JM, Aminian S, Jebb SA, Butler G, Cheetham T, O'Rahilly S. Dominant and recessive inheritance of morbid obesity associated with melanocortin 4 receptor deficiency. J Clin Invest 2000; 106:271-9

15 Jacobson P, Ukkola O, Rankinen T, Snyder EE, Leon AS, Rao DC, Skinner JS, Wilmore JH, Lonn L, Cowan GS Jr. Sjostrom L, Bouchard C. Melanocortin 4 receptor sequence variations are seldom a cause of human obesity: the Swedish Obese Subjects, the HERITAGE Family Study, and a Memphis cohort, $J$ Clin Endocrinol Metab 2002;87:4442-6.

16 Allison DB, Heo M, Faith MS, Pietrobelli A. Meta-analysis of the association of the Trp64Arg polymorphism in the beta3 adrenergic receptor with body mass index. Int J Obes Relat Metab Disord 1998;22:559-66.

17 Fujisawa T, Ikegami H, Kawaguchi Y, Ogihara T. Meta-analysis of the association of Trp64Arg polymorphism of beta 3-adrenergic receptor gene with body mass index. J Clin Endocrinol Metab 1998;83:2441-4.

18 Heo M, Leibel RL, Fontaine KR, Boyer BB, Chung WK, Koulu M, Karvonen MK, Pesonen U, Rissanen A, Laakso M, Uusitupa MI, Chagnon Y, Bouchard C, Donohoue PA, Burns TL, Shuldiner AR, Silver K, Andersen RE, Pedersen O, Echwald S, Sorensen TI, Behn P, Permutt MA, Jacobs KB, Elston RC Hoffman DJ, Gropp E, Allison DB. A meta-analytic investigation of linkage and association of common leptin receptor (LEPR) polymorphisms with body mass index and waist circumference. Int J Obes Relat Metab Disord 2002;26:640-6.

19 Dempfle A, Hinney A, Heinzel-Gutenbrunner M, Raab M, Geller F Gudermann T, Schäfer $H$, Hebebrand J. Large quantitative effect of melanocortin-4 receptor gene mutations on body mass index. J Med Genet 2004:41:795-800.

20 Gu W, Tu Z, Kleyn PW, Kissebah A, Duprat L, Lee J, Chin W, Maruti S Deng N, Fisher SL, Franco LS, Burn P, Yagaloff KA, Nathan J, Heymsfield S, Albu J, Pi-Sunyer FX, Allison DB. Identification and functional analysis of novel human melanocortin-4 receptor variants. Diabetes 1999;48:635-9. 